\title{
The Development of Lesson Study in History for Social Science Learning in Elementary School
}

\author{
Muhamad Chamdani ${ }^{1}$, Wahyudi ${ }^{1}$ \\ ${ }^{1}$ Lecturer of Elementary School Teacher Education of Teacher Training and Education \\ Faculty of Universitas Sebelas Maret, $6^{\text {th }}$ Campus of Kebumen \\ e-mail: muhamad_chamdani@staff.uns.ac.id
}

\begin{abstract}
This study was a research and development of historical material of social science learning with lesson study model. The data sources of research were students, peer, teacher, and authors. The data was collected through observation, questionnaire, and written test. The objectives of research were: (1) to develop learning set including syllabus and learning implementation plan of lesson study in history material of social science subject, (2) to evaluate the feasibility of lesson study syllabus and learning implementation plan in history material of social science subject, (3) to measure the effectiveness of lesson study syllabus and learning implementation plan product application in history material of social science subject, (4) and to measure the implementation of lesson study and the effectiveness of learning in history material of social science subject. The method employed was Richley and Klein's method consisting of four measures: need analysis on syllabus and learning implementation plan, designing syllabus and learning implementation plan, developing syllabus and learning implementation plan, and evaluating syllabus and learning implementation plan. The result of external trial showed mean score of 79.62, fulfilling the minimum passing criteria. The mean score of students' learning attitude was 3.206, belonging to often category. The mean score of presentation skill was 82.86 , belonging to good category. The mean score of students' response to language content and use was 2.96, belonging to good category, and the observers' response was 2.54 , belonging to very good category.
\end{abstract}

\section{Keywords: lesson study; social science learning; history material.}

\section{INTRODUCTION}

\section{Learning quality improvement Issue}

Some historical education practitioners or historicist argue on the historical learning phenomenon occurring in Indonesia, including historical learning model, history curriculum, material problem, and textbook, history teacher professionalism and etc.

Regarding historical learning model problem, Alfian [1] states that the reality shows that historical learning is far below the expectation to enable the students to see its relevance to the present and the future. From primary to secondary school 
level, historical learning tends to utilize historical fact only as the main material. It is unsurprising that historical education seems to be dry, unattractive, and not giving the students the opportunity of learning to explore the meaning of historical event.

Pedagogic strategy of Indonesian history is very weak. Historical education in school is still wrestling with chronicle approach and tends to require the students to recite or to memorize an event (Abdullah in Alfian [1]). The students were not accustomed to define an event in order to understand the dynamics of change.

Historical learning system developed is actually inseparable from the entrenching cultural effect. A one-way learning model in which teacher becomes the primary source of knowledge in learning activity is difficult to change. Historical learning today makes the role of students as the historical actor in their time neglected. The experiences the previous students or their social environment has are not made the learning material in the class, thereby putting the students to be passive participants of historical learning (Martanto, et al [2]). In other words, the less precisely selected teaching strategy will result in fatalism to the achievement of learning objective (Widja [3]).

Historical curriculum problem occurs due to the curriculum constituting one component to which the achievement of national education objective refers. Generally, it can be said that curriculum is a written plan implemented in an education process to develop the students' potency. Curriculum contains such components as objective, content and content organization, process describing the position of students in learning and learning outcome assessment. In addition to those components, curriculum as a written plan may contain learning source and learning instrument and curriculum or program evaluation (Hamid Hasan [4]).

Since Indonesian independence, curriculum has changed several times and history subject is included within it. However, the materials available in curriculum are often criticized by community and historical observers for its selection, development theory and implementation frequently used to support the power (Alfian, [1]).

History teacher professionalism is also questioned; until today, teachers and policy makers in school still consider that history learning is not so important in the term profession that history teaching duty is often given to its non-professional teacher. As a result, teachers teach history with lecturing method by repeating the content of book (Anggara [5]). Meanwhile, too many schools position history teacher as the exile and history subject serves as complement only. Even in many cases, history teachers are found to be the target to raise the students' score to make the corresponding rise onto the next grade. In addition, most teachers do not follow the development of research result and the recent publication of Indonesian history. The latter is also related to the reality that official institution becomes the history teacher's additional education place in historical substance and left behind history teaching method (Purwanto [6]).

History teaching implemented in school so far is less optimum. History subject is as if very easy and underestimated. Many educators with non history education background are forced to teach history in school (Hariyono [7]). The image of history subject among Indonesian students is low. Students consider history subject as not beneficial to their life in both the present and the future. History subject is replete with recitation, unimportant, and boring (Sayono [8]). Negative perspective on history learning can be due to non-qualified history teacher resulting from its 
creating institution. Educator and education staff institution is teacher training institution existing in Indonesia today. Fasli Jalal, et.al. [9] states that government has assigned educator and education staff institution to meet the target of national education and to improve knowledge and professional skill in education sector through research and training, curriculum improvement and professionalism development, as the one responsible for providing the sufficient number of teachers.

Considering historical learning issue and problem in elementary school, learning development is required to answer the problem existing with lesson study learning model as the attempt of improving historical learning quality. Lesson study is an educator professionalism building model through collaborative and sustainable learning research based on collegial and mutual learning principles to build learning community (Hendayana, Sumar et.al [10]). Through lesson study activity, a learning model is developed to encourage the students to learn actively, creatively, effectively, and joyfully through hand-on dart mind-on activity, daily life, dart local material (Hendayana [10]). A well-designed lesson study activity serves potentially to be a means of developing teacher competency in supporting its professionalism duty (Mahmudi [11]). The implementation of lesson study program and the role of headmaster in lesson study program can be conducted due to cooperation support between teacher, headmaster, and coordinator roles in organizing the program. Lesson study is an approach to improve learning in Japan. The form of professional teacher development movement initiated in Japan is intended to improve the students' teaching and learning progress (Anne, et.al [12]). The teaching focuses on collaborative teaching plan of observing and direct debriefing (Lewis, Perry, and Murrata [13], Stigler and Hiebert [14]). Lewis [14] describes the process as the teachers' collaborative measures to plan, observe, and reflect on the lesson. Lesson study is a complex process supported by a collaborative objective organization, observation in collecting data of students' learning and consensus to give opportunity of productive discussion about difficult issues. Lesson study is essentially a sustainable cyclical activity having practical implication to education.

Lesson study is one of teacher professionalism development strategies. Teacher group develops learning collectively, in which a teacher is assigned to implement the learning, and the others observe students' learning. This process is conducted during the learning process, in the end of activity, teachers assemble and make debriefing about the learning conducted, revise and organize the next learning based on the result of discussion. Lesson study activity, in addition to involving teachers as collaborator, also involves lecturers of education staff training institution and other relevant parties in developing an effective learning implementation program. More simply, LS cycle can be done through a series of practical activities: PlanningDoing-Seeing (Plan-Do-See).

Planning (Plan) stage is the stage aiming to produce a learning design believed as enabling the students to learn effectively and generating the students' participation in learning. In planning, teachers share idea collaboratively, design the learning to produce the way of organizing teaching material, learning process, and preparing learning aid to be implemented in the class. In this stage, observation procedure and instrument needed are determined.

Doing $(D o)$ stage aims to implement learning design. In the implementation process, one teacher serves as the executor of lesson study and others as observer. The observation focuses not on the appearance of teachers teaching but on the 
students' learning activity referring to procedure and instrument agreed in planning stages.

Reflecting (see) stage aims to find the strength and the weakness of learning implementation. The activity starts with delivering the learners' impression to be given to the observer. Critique and recommendation are given in the attempt of improving the learning quality and delivered wisely without underestimating or hurting the teachers' heart. Positive input can be used to design better learning. The learning is the heart of education process in an education institution. Learning quality is complex and dynamic, can be viewed from many perceptions and perspective crossing time border. At micro level, the achievement of learning quality is a teacher professionalism responsibility, for example, through creating a meaningful learning experience for students and providing facilities for the students to achieve the maximum learning outcome. At macro level, through a high-quality learning system, the education institution is responsible for creating high-quality teaching staffs by contributing to intellectual, attitude, and moral development of individual students as the members of society (Hamid Hasan [4]).

Teacher education and building should be improved to create adequate number of high-quality teachers, so should be their career development and welfare, by rewarding the high-achieving teachers (Musnir in Gunawan[16]). Therefore, history teachers should have understanding professionally on the essence of historical learning, the objective of historical learning, the competencies to be developed in historical learning, and the values needed and to be developed in historical learning, before the teachers determine the method or approach used later (Anggara [5]). The problem statements of research are: (1) what are the characteristics of learning set including lesson study syllabus and learning implementation plan in history material of social science subject? (2) how is the feasibility of lesson study syllabus and learning implementation plan products? (3) how is the effectiveness of lesson study syllabus and learning implementation plan in history material of social science subject? (4) how are the response of lesson study implementation and the effectiveness of learning in history material of social science subject? The objectives of research were (1) to develop the learning set including lesson study syllabus and learning implementation plan in history material of social science subject, (2) to evaluate the feasibility of lesson study syllabus and learning implementation plan products, (3) to measure the effectiveness of lesson study syllabus and learning implementation plan in history material of social science subject, and (4) to measure the lesson study implementation and the effectiveness of learning in history material of social science subject.

\section{METHOD}

The method employed in this research was research and development (R\&D) one. This R\&D method was used to develop lesson study syllabus and learning implementation plan. This research \& development of lesson study syllabus and learning implementation plan employed Richey and Klein's development model. This development model employs four measures: analysis, design, development, and evaluation. Research design used was internal and external tryouts. Internal tryout validated lesson study syllabus and learning implementation plan products and 
research instrument. External tryout assessed learning effectiveness, student learning activity, and lesson study implementation level. Techniques of collecting data used were observation and interview, questionnaire, and written test. Meanwhile, research instruments used were observation and interview sheets, questionnaire, and questions. Meanwhile, the research analysis was conducted using statistic descriptive analysis (question item and categorization) and inferential statistic analysis (estimating validity and reliability of expert judgment.

\section{RESULT AND DISCUSSION}

\section{Lesson Study Implementation}

\section{PLAN}

Planning is conducted in four ways. Firstly, community team is established in school. The competent individual is selected to be team leader in implementing lesson study. Secondly, team discusses the topic to be implemented through lesson study. Thirdly, team discusses the problems occurring in the field related to syllabus and learning implementation plan application. Fourthly, team develops a plan of developing lesson study syllabus and learning implementation plan. Fifthly, team conducts need analysis, interview and observation on teachers and stakeholders. The result of analysis was used as the reference in drafting syllabus design and learning implementation plan. Sixthly, team develops an instrument of assessing syllabus and learning implementation plan; the response to lesson study learning process and the response to the instrument of assessing syllabus and learning implementation plan are validated by the experts including lecturers and teachers used as improvement before learning implementation. The team leader concludes and closes the discussion activity.

DO

First Meeting

Firstly, team leader opens the activity before the learning starts. Every member checks the equipment used for learning. Secondly, model teacher and observer enter into class. Thirdly, model teacher deliver material introduction and learning objective. Fourthly, teacher divides students into groups to discuss the learning material. Fifthly, every group discusses the problem given by teacher. Sixthly, the students discuss and find the answer using book or other media. Seventhly, individual students are encouraged to express their opinion in each of groups. Eighthly, the students' opinion is recorded by other members of group and presented. Ninthly, model teacher asks the group to question. Tenthly, model teacher directs the students and corrects the result of question made. Eleventh, teacher and students deliver the material learnt and close the learning.

Second Meeting

Firstly, team leader checks the assignment to be worked on during the learning process. Secondly, model teacher deliver the learning material. Thirdly, model teacher delivers history material in social science learning. Fourthly, model teacher 
assigns the students to work on history material. Fifthly, the students prepare any equipment to be used in historical learning. Sixthly, the students ask the teacher about certain part in history material. Seventhly, the students are assigned to work on the students' worksheet in history material of social science learning. Eighthly, model teacher closes learning process. Ninthly, each student activity consists of paying attention to the material presenter, preparing the assignment the model teacher gave and writing a simple report.

SEE

Firstly, team leader opens discussion related to learning evaluation in two meetings. Secondly, model teacher delivers the student's message and learning outcome. Thirdly, observer delivers observation result on the two meetings. Fourthly, the result of model teacher and observer's delivery is analyzed particularly for the activity of students who have learnt well and that of those who have not learnt well. Fifthly, solution is sought to make the students studying joyfully and comfortably thereby understanding the material taught. Sixthly, the solution becomes a reference for planning the next meeting. Seventhly, when the learning objective has been achieved, the team unnecessarily designs the next learning. Eighthly, in learning implementation, the team writes the research report after the data collection has been completed. Ninthly, before writing data report, validity and reliability are tested first.

The result of research shows that the need analysis conducted based on interview with model teacher obtains some points: firstly, learning hour adjustment; secondly research development adjusted with the school's need; thirdly, routinely evaluation implementation; and fourthly, scientific approach application adjusted with the learning characteristics.

The result of need analysis shows firstly, the importance of cooperation between teacher and many stakeholders; secondly the learning consistent with the need today; thirdly, the similarity of learning assessment to the students' need; and fourthly, the need for discussing the learning design by applying lesson study.

The data shown in table of analysis on teachers' need for syllabus and learning implementation plan indicates that the syllabus assessment product has mean score of 3.54 , belonging to a very agree category. Meanwhile, mean score of teachers' response to learning implementation plan product is 3.46 , belonging to a very agree category. Meanwhile, the mean score of response to work partner is 3.42 belonging to very agree category.

The designing stage employing the same respondents with analysis stage obtains data from questionnaire and interview aiming to find out the product design indicating that mean score of teachers' response to the syllabus assessment product is 3.6, belonging to very agree category. Meanwhile, the score of teacher's response to product design is 3.42 , belonging to very agree category. From the interview with teachers, some inputs are given to product designing. Firstly, the development of syllabus and learning implementation plan should be developed synergistically. Secondly, the development of syllabus and learning implementation plan can be applied through lesson study. Firstly, lesson study should be socialized. Thirdly, syllabus and learning implementation plan should be developed referring to the guidelines of 2013 curriculum comprehensively. Meanwhile, data of need analysis 
on syllabus and learning implementation plan product assessment shows mean score of 3.5 , belonging to very agree category.

Considering the result of interview with sub district education service, some inputs are given: firstly, work culture should be socialized to the students; secondly, there should be cooperation in designing competency-based learning. Thirdly, the assessment of knowledge, attitude, and skill should be assessed for developing students' character. Fourthly, the learning employs scientific approach adjusted with the students' need.

From the data of analysis and designing stages, lesson study syllabus and learning implementation plan products are obtained referring to Education and Culture Minister's Regulation Numbers 65 of 2013 and 103 of 2014. This product has some advantages over other syllabus and learning implementation plans. The advantages of lesson study are (a) the development is conducted comprehensively, (b) the application process uses lesson study, (3) learning activity applies scientific approach, and (d) assessment is conducted authentically and comprehensively. Meanwhile, the advantages of lesion study learning implementation plan are (a) competency is taught comprehensively, (b) the learning implementation plan is applied in the learning using lesson study, (c) learning activity uses scientific approach, and (d) assessment is conducted authentically and supported with assessment guidelines and instruments.

Data of product evaluation stage is validated and implemented in teachinglearning process. This evaluation stage employs internal and external tryout. Internal tryout is obtained from instrument validation, instrument reliability test, and product reliability test. Meanwhile, the instrument includes syllabus and learning implementation plan, and teacher's, observer's, and student's responses. Product validation is carried out by assessing the lesson study syllabus and learning implementation plan. From the result of evaluation on internal tryout, the following data is obtained. Instrument scores 0.572 belonging to medium category, syllabus product 0.43 to very high category, learning implementation plan 0.844 to very high category, instrument reliability 0.632 to good category, syllabus reliability 0.834 to very good category, and learning implementation plan reliability 0.737 to very good category.

Furthermore, data of external tryout result shows the mean score of knowledge assessment of 79.62, fulfilling the minimum passing criteria of 77 . The score of student's learning attitude is 3.206 , belonging to often category, that of presentation skill assessment is 82.86 to good category, that of students' response to content and language use is 2.96 to good category, and that of observer's response is 3.54 to very good category. The assessment of students' learning attitude is divided into two: skill rating and anecdote recording. From the skill presented comprehensively, it can be stated that the social science learning using lesson study in history material can be implemented well.

Considering the assessment on teachers' ability of managing the learning, the scores the observers give using observation sheet, learning implementation, and observation result analysis are as follows. In learning 1 and 2, two observers give mean score of 3.54, meaning that the learning has been implemented very well. Nevertheless, observers note that: (1) technique of exploring the children's questioning ability is very good, as reflected on the children taking the next turn to question each other, (2) students' response is fairly good, including in responding to 
friend's opinion in group, (3) the presentation in louder voice can yield more maximal output. In combining some learning contents and scientific approaches, time allocation is conducted appropriately. Based on the analysis of students' response to learning implementation, questionnaire sheet is used; the result shows that all students state that the learning circumstance and the teachers' teaching method are attractive. The analysis of cognitive learning outcome obtains the score above minimum passing criteria. That of affective learning outcome shows a good result.

\section{CONCLUSION}

From the development of lesson study in history material of social science learning, the following conclusions can be drawn. (1) The development of lesson study syllabus and learning implementation plan in history material of social science learning brings about mutual learning characteristics and uses scientific approach. (2) The assessment of product shows that the product in the form of lesson study syllabus and learning implementation plan in history material of social science is feasible to use. (3) The effectiveness of learning in knowledge (cognitive) aspect is higher than standard minimum passing criteria. Viewed from attitude (affective) aspect, overall all students learn more actively. The observation on skill (psychomotor) aspect obtains higher score than the standard minimum passing criteria. (4) Teachers' and observer's response to the implementation of lesson study syllabus and learning implementation in history material of learning science is very good. Meanwhile, the students' response to the effectiveness of social science learning in history material belongs to good category.

\section{REFERENCES}

[1] Alfian, Magdalia. 2007. 'Pendidikan Sejarah dan Permasalahan yang Dihadapi'. Makalah. Disampaikan dalam Seminar Nasional Ikatan Himpunan Mahasiswa Sejarah Se-Indonesia (IKAHIMSI). Universitas Negeri Semarang, Semarang, 16 April 2007

[2] Martanto, SD, dkk. 2009. 'Pembelajaran Sejarah Berbasis Realitas Sosial Kontemporer Untuk Meningkatkan Minat Belajar Siswa'. PKM-GT. Semarang. Tidak Dipublikasikan

[3] Widja, I Gde. 1989. Dasar - Dasar Pengembangan Strategi Serta Metode Pengajaran Sejarah. Jakarta : Debdikbud.

[4] Hasan, Hamid S. 2007. 'Kurikulum Pendidikan Sejarah Berbasis Kompetensi'. Makalah. Disampaikan dalam Seminar Nasional Ikatan Himpunan Mahasiswa Sejarah Se-Indonesia (IKAHIMSI). Universitas Negeri Semarang, Semarang, 16 April 2007

[5] Anggara, Boyi. 2007. 'Pembelajaran Sejarah yang Berorientasi pada Masalah- Masalah Sosial Kontemporer'. Makalah. Disampaikan dalam Seminar Nasional Ikatan Himpunan Mahasiswa Sejarah Se-Indonesia (IKAHIMSI). Universitas Negeri Semarang, Semarang, 16 April 2007

[6] Purwanto, Bambang. 2006. Gagalnya Historiografi Indonesiasentris?!. Yogyakarta : Ombak

[7] Hariyono. 1995. Mempelajari Sejarah Secara Efektif. Jakarta : Pustaka Jaya

[8] Sayono, J. (2013). Pembelajaran Sejarah di Sekolah: dari Pragmatis ke Idealis. Sejarah dan Budaya, 7(1), 9-17.

[9] Jalal, F., Samani, M., Mae, C., Stevenson, R., Ragartz, A., \& Negara, S. (2009). Teacher Certification in Indonesia: A Strategy for Teacher Quality Improvement. Jakarta: Departemen Pendidikan Nasional. 
[10] Hendayana, Sumar. 2007. Lesson Study Suatu Strategi Meningkatkan Keprofesionalan Pendidik. Bandung: UPI Press.

[11] Mahmudi, Ali. 2009. Mengembangkan Kompetensi Guru Melalui Lesson Study. Jurnal FORUM KEPENDIDIKAN, VOLUME 28, NOMOR 2, MARET 2009.

[12] Halvorsen, Anne-Lise \& Alisa Kesler Lund (2013). Lesson Study and History Education. The Social Studies, 104:3, 123-129. DOI : 10.1080/00377996.2012.698326.

[13]Lewis, Catherine, Rebecca Perry, and Aki Murata. "How Should Research Contribute to Instructional Improvement : A Case of Lesson Study. "Educational Researcher35, no. 3 (2006) : 3-14.

[14] Stigler, James W., and James Hiebert. The Teaching Gap : Best Ideas from the World's Teacher for Improving Education in the Classroom. New York : Summit Books, 1999.

[15] Lewis, Catherine. "Lesson Study : The Core of Japanese Profesional Development. "Invited address at the annual meeting of the American Educational Research Association. New Orleans, LA, April 28, 2000.

[16] Gunawan, Restu (ed). 1998. Simposium Pengajaran Sejarah (kumpulan makalah diskusi). Jakarta : Depdikbud

[17] Abizar, Haris. 2017. Buku Master Lesson Study. Yogyakarta : Diva Press.

[18] Kochar, S.K. 2008. Pembelajaran Sejarah. Jakarta : Grasindo

[19] Santyasa, I Wayan. 2009. “Implementasi Lesson Study dalam Pembelajaran”. Makalah disajikan dalam Seminar Implementasi Lesson Study dalam Pembelajaran bagi Guru-guru TK, Sekolah Dasar, dan Sekolah Menengah Pertama di Kecamatan Nusa Penida, Nusa Penida, 24 Januari 2009. http://www.freewebs.com/santyasa/ pdf2/ IMPLEMENTASI_LESSON_STUDY.pdf, diakses 23 Oktober 2012. 